\section{Partial Budget Analysis of Summer Fallows for Organic Nutrient and Weed Management in Florida}

\author{
Alyssa H. Cho ${ }^{1}$, Alan W. Hodges ${ }^{2}$, and Carlene A. Chase ${ }^{3}$
}

AdDITIONAL INDEX WORDs. cover crop, sunn hemp, Crotalaria juncea, velvet bean, Mucuna deeringiana, cowpea, Vigna unguiculata, sorghum-sudangrass, S. bicolor $\times S$. bicolor var. sudanense, tillage

\begin{abstract}
SumMary. Partial budget analyses of five summer fallow treatments in Florida preceding a cash crop of summer squash (Cucurbita pepo) were conducted. The five treatments were sunn hemp (Crotalaria juncea), velvet bean (Mucuna deeringiana), cowpea (Vigna unguiculata), sorghum-sudangrass (Sorghum bicolor $\times$ S. bicolor var. sudanense), and tillage. Costs were estimated for each summer fallow treatment, including the cost of seed, inoculant, implementation, management, and termination. Benefits were calculated in terms of contributions to the following cash crop of summer squash in the form of biologically fixed nitrogen and reduced weed pressure. Results showed that total production costs were minimized by cover crops, even though implementation costs were higher than for tillage.
\end{abstract}

$\mathrm{F}$ lorida ranks fifth in the nation for vegetable production occurring on 265,835 acres with a market value of $\$ 2.65$ billion in 2007 [U.S. Department of Agriculture (USDA), 2009]. Florida agriculture capitalizes on a market window for fruits and vegetables during the winter and spring months that other states cannot meet because of climatic limitations, thereby often receiving higher prices.

As demand for organic produce increases, growers are attracted to organic production since price premiums can offset the higher production costs. According to the 2008 Organic Production Survey from the USDA census of agriculture, 14,540 organic farmers and ranchers used 4.1 million acres of land in the United States with \$3.16 billion in total crop and livestock sales (USDA, 2010). However, organic producers face challenges in meeting the National Organic Program (NOP) standards for organic certification.

According to the NOP, organic producers must use inputs for production that are from natural sources and will have minimal impacts on the environment (USDA, 2000). Nutrient management for organic production requires attention and careful application to provide sufficient

${ }^{1}$ University of Florida, Horticultural Sciences Department, P.O. Box 110690 Gainesville, FL 32611

${ }^{2}$ University of Florida, Food and Resource Economics Department, P.O. Box 110240, Gainesville, FL 32611

${ }^{3}$ Corresponding author. E-mail: cachase@ufl.edu. quantities of nutrients that are available for use by the crop at the appropriate time. A survey found that the three most common sources of nutrients used by organic producers in Florida were 1) animal (especially chicken) manure, 2) bagged organic fertilizers, and 3) fish emulsion (Swisher and Monaghan, 1995). It was noted that the bagged fertilizers were also mostly based on poultry manure. Hildebrand et al. (1997) surveyed northern Florida organic growers and also found that chicken manure ranked first and fish emulsion as the second most commonly used source of fertilizer. The major constraints of using natural sources of fertilizers are the bulky nature and the heavy application rates needed to meet the nutrient requirements of the cash crop. The average nitrogen $(\mathrm{N})$ content of chicken manure is 26-72 $\mathrm{lb} /$ ton of manure, and application rates are commonly 5-25 tons/acre per year (Ferguson and Ziegler, 2004). Utilization of an on-site source of $\mathrm{N}$ greatly reduces an organic grower's need for off-site nutrients. A solution for organic growers to reduce their fertilizer costs is to add a cover crop into their cropping system that increases the nutrient availability in their soils. Leguminous cover crops can provide biologically fixed $\mathrm{N}$ to the soil in addition to providing other benefits, such as soil stability, water retention, reduced erosion, and cycling of other nutrients.

An additional consideration for organic producers is weed management (Walz, 1999). Organic producers are limited to cultural practices, mulching with fully biodegradable mulches, mowing, livestock grazing, hand weeding, mechanical cultivation, flame or heat, and plastic or synthetic mulches, which must be removed at the end of the season (USDA, 2000). If these methods are not sufficient in managing weed populations, organic growers may use biological or botanical substances (USDA, 2000). However, a few nonsynthetic herbicides are currently available, and these substances for weed management are allowed only as a last resort option, and are often expensive.

Hildebrand et al. (1997) found that in north-central Florida weed management was the major constraint to switching from conventional to organic production. Weeds also limit the expansion of organic production. A strong reliance on hand hoeing and mechanical cultivation for weed management by Florida's organic vegetable growers was reported by Swisher and Monaghan (1995). Although the NOP allows application of permitted herbicides and other weed management techniques, organic producers continue to rely heavily on human labor and mechanical equipment to manage weed populations. The majority of organic producers in Florida manually cultivate as often as five to six times during a growing season to manage weeds (Swisher and Monaghan, 1995).

\begin{tabular}{llll}
\hline $\begin{array}{l}\text { Units } \\
\begin{array}{l}\text { To convert U.S. to SI, } \\
\text { multiply by }\end{array}\end{array}$ & U.S. unit & SI unit & $\begin{array}{l}\text { To convert SI to U.S., } \\
\text { multiply by }\end{array}$ \\
\hline 0.4047 & acre $(\mathrm{s})$ & $\mathrm{ha}$ & $2.471 \mathrm{l}$ \\
3.7854 & $\mathrm{gal}$ & $\mathrm{L}$ & 0.2642 \\
9.3540 & $\mathrm{gal} / \mathrm{acre}$ & $\mathrm{L} \cdot \mathrm{ha}^{-1}$ & 0.1069 \\
0.4536 & $\mathrm{lb}$ & $\mathrm{kg}$ & 2.2046 \\
1.1209 & $\mathrm{lb} / \mathrm{acre}$ & $\mathrm{kg} \cdot \mathrm{ha}^{-1}$ & 0.8922 \\
0.5 & $\mathrm{lb} /$ ton & $\mathrm{kg} \cdot \mathrm{Mg}^{-1}$ & 2 \\
0.9072 & ton(s) & $\mathrm{Mg}$ & 1.1023 \\
2.2417 & ton/acre & $\mathrm{Mg} \cdot \mathrm{ha}^{-1}$ & 0.4461
\end{tabular}


With the cost of fuel and labor rising and possible adverse effects of frequent cultivation, organic weed management could benefit from a more ecological approach.

In Florida, organic producers generally do not grow crops during the hot, humid, summer months. This break in their crop production cycle is often left as a weedy or clean (usually with tillage) fallow. Although tillage suppresses weed populations to an extent, tillage can build the weed seed bank and spread weed seeds (Froud-Williams et al., 1983). Additionally, tillage is sometimes overused, and uses labor, machinery, and fuel that could otherwise be spared, and can contribute to soil erosion and loss of nutrients. Florida organic producers could use cover crops or green manures as tools for managing weed populations and as an alternative to a weedy fallow during the summer months. Despite the significant amount of literature and data to support the adoption of cover crops into cropping systems for environmental reasons, few economic studies of the use of cover crops have been conducted, and a gap exists in the understanding the economics of using cover crops (Lu et al., 2000). The costs associated with establishing a cover crop (seed and management) are easy to evaluate, but the benefits that do not have economic values are often excluded from the economic considerations of cover crop use. There is a need to appoint economic values to the benefits that cover crops provide to a cropping system.

Cash crops following cover crops often experience reductions in weed populations as compared with cash crops following a weedy fallow. These reductions can lead to benefits including an increase in cash crop productivity and potential reductions in pest pressure (Li et al., 2006). In organic systems, this reduction in weed populations could mean a decrease in labor costs associated with hand weeding. Although the importance of weed suppression by cover crops is well documented, economic data are lacking to support the monetary benefits growers might obtain by using a cover crop in place of a weedy fallow (Snapp et al., 2005). Sangakkara et al. (2006) evaluated crops that could be used in place of weedy fallows in tropical farming systems. Weed suppression by a cover crop correlates to the biomass production of that crop (Klassen et al., 2006). Sunn hemp produced the most groundcover and, therefore, the greatest weed suppression in comparison with other cover crops, suppressing $50 \%$ to $82 \%$ of weeds (Sangakkara et al., 2006). The study also showed that a cash crop of mung bean (Vigna radiata) following the sunn hemp fallow had the lowest weed populations.

Many growers recognize the benefits of integrating a cover crop into their cropping systems; however, it is difficult to justify the costs to implement these cover crops. The objective of this study was to conduct economic analyses of summer fallow treatments in Florida. The economic analyses were focused on the evaluation of the costs for cover crop establishment and management and on the appointment of economic values to cover crops, emphasizing the nutrient accumulation and the weed suppressive capabilities and how these benefits interact with the overall cash flow of the cropping system.

\section{Materials and methods}

Data from several sources were used in this study to create partial budgets for five summer fallow treatments: sunn hemp, velvet bean, cowpea, sorghum-sudangrass, and use of tillage to manage weeds preceding a summer squash crop. Partial budget analyses are used to evaluate the relevant costs and incomes induced from adopting a proposed change in a business practice. In this study, the proposed change is the utilization of a summer fallow treatment in a production system. The sources used in these analyses included studies on the characteristics of the cover crops included, as well as squash production budgets (Hewitt, 2006; Klassen et al., 2006; Li et al., 2006; Lu et al., 2000; Schomberg et al., 2007). For the partial budgets, the main considerations were the cost of the summer fallow treatments and the benefits that can be observed in a following cash crop from the treatments. The benefits valued in this study were the reduction in weed populations and $\mathrm{N}$ contribution in the following cash crop following the summer fallow treatment.

Table 1 outlines the biomass and $\mathrm{N}$ accumulation of each cover crop species used as a treatment and the recommended seeding rates. Tables 2 and 3 list the costs of implementing the cover crop and tillage treatments, respectively, not including the cost of seed and inoculant. A breakdown of these variable costs (seed and inoculant) can be found in Table 4, as well as the total cost of establishing each fallow treatment.

Since the level of weed suppression by sunn hemp will be highly dependent on the existing weed populations as well as the planting densities of the cover crop, this study used $70 \%$ reduction as an average for weed suppression by sunn hemp (Sangakkara et al., 2006). Weed reduction values were appointed to the other cover crop species based on

Table 1. Varieties and characteristics of summer cover crops evaluated for economic feasibility in Florida as rotations with summer squash.

\begin{tabular}{|c|c|c|c|c|c|}
\hline Cover crop & Best variety $^{z}$ & Vigor $^{\mathrm{z}}$ & $\begin{array}{l}\text { Seeding rate } \\
(\mathrm{lb} / \mathrm{acre})^{\mathrm{z}, \mathrm{y}}\end{array}$ & $\begin{array}{l}\text { Nitrogen in cover crop } \\
(1 \mathrm{~b} / \mathrm{acre})^{\mathrm{x}}\end{array}$ & $\begin{array}{l}\text { Maximum dry } \\
\text { matter yield } \\
{\text { (tons } / \text { acre })^{\mathrm{y}, \mathrm{x}}}\end{array}$ \\
\hline Sunn hemp & Tropic Sun & Excellent & 50 & 300 & 5 \\
\hline Cowpea & Iron Clay & Good & 100 & 86 & 3 \\
\hline Sorghum-sudangrass & - & Good & 40 & 33 & 2 \\
\hline
\end{tabular}

${ }^{2}$ Abdul-Baki and Teasdale, 2007.

${ }^{y} \mathrm{lb} / \mathrm{acre}=1.1209 \mathrm{~kg} \cdot \mathrm{ha}^{-1}, \mathrm{l}$ ton $/ \mathrm{acre}=2.2417 \mathrm{Mg} \cdot \mathrm{ha}^{-1}$.

${ }^{\times} \mathrm{Li}$ et al. 2006. 
Table 2. Partial budget for implementation of a summer cover crop as a summer fallow treatment in rotation with summer squash in Florida excluding the cost of seed and inoculant of the cover crop based on 1 acre $(0.4$ ha) of land.

\begin{tabular}{|c|c|c|c|c|}
\hline Variable costs & Unit & $\begin{array}{c}\text { Quantity } \\
\text { (units/acre) }^{\mathrm{z}}\end{array}$ & Price $(\$ / \text { unit })^{\mathrm{z}}$ & Cost $(\$ / \text { acre })^{2}$ \\
\hline Operator labor ${ }^{\mathrm{y}}$ & Hour & 2.14 & 10.90 & 23.33 \\
\hline Heavy disc & Hour & 0.16 & 7.97 & 1.28 \\
\hline Moldboard plow & Hour & 0.43 & 7.87 & 3.38 \\
\hline Rotary mower & Hour & 0.34 & 7.97 & 2.71 \\
\hline Planter & Hour & 0.14 & 9.17 & 1.28 \\
\hline Diesel fuel $^{x}$ & Gallon & 0.21 & 3.51 & 0.74 \\
\hline Total variable costs & & & & 32.72 \\
\hline \multicolumn{5}{|l|}{ Fixed costs } \\
\hline Heavy disc & Hour & 0.16 & 9.50 & 1.52 \\
\hline Moldboard plow & Hour & 0.43 & 9.40 & 4.04 \\
\hline Rotary mower & Hour & 0.34 & 8.40 & 2.86 \\
\hline Planter & Hour & 0.14 & 11.60 & 1.62 \\
\hline Total fixed & & & & 10.04 \\
\hline Total costs & & & & 42.76 \\
\hline
\end{tabular}

${ }^{2} 1 \mathrm{~h} /$ acre $=2.4711 \mathrm{~h} \cdot \mathrm{ha}^{-1}, 1 \mathrm{gal} / \mathrm{acre}=9.3540 \mathrm{~L} \cdot \mathrm{ha}^{-1}, \$ 1.00 /$ gal $=\$ 0.2642 / \mathrm{L}, \$ 1.00 /$ acre $=\$ 2.471 \mathrm{l} / \mathrm{ha}$. "Florida Department of Economic Opportunity, 2010; Hewitt, 2006.

${ }^{x}$ Downs and Hansen, 1998; U.S. Energy Information Administration, 2012.

Table 3. Partial budget for tillage treatment for management of weeds during summer fallow in rotation with summer squash in Florida based on 1 acre (0.4 ha) of land.

\begin{tabular}{|c|c|c|c|c|}
\hline Variable costs & Unit & $\begin{array}{c}\text { Quantity } \\
\text { (units/acre) }^{\mathrm{z}}\end{array}$ & Price $(\$ / \text { unit })^{\mathrm{z}}$ & Cost $(\$ / \text { acre })^{z}$ \\
\hline Operator labor ${ }^{\mathrm{y}}$ & Hour & 3.54 & 10.90 & 38.59 \\
\hline Heavy disc & Hour & 0.48 & 7.97 & 3.83 \\
\hline Moldboard plow & Hour & 1.29 & 7.87 & 10.15 \\
\hline Diesel fuel $^{\mathrm{x}}$ & Gallon & 0.34 & 3.51 & 1.19 \\
\hline Total variable costs & & & & 53.76 \\
\hline \multicolumn{5}{|l|}{ Fixed costs } \\
\hline Heavy disc & Hour & 0.48 & 9.50 & 4.56 \\
\hline Moldboard plow & Hour & 1.29 & 9.40 & 12.13 \\
\hline Total fixed costs & & & & 16.69 \\
\hline Total costs & & & & 70.45 \\
\hline
\end{tabular}

existing data for biomass production and the baseline weed reduction provided by sunn hemp (Table 5 ). Similarly, $\mathrm{N}$ accumulation was based on documented biomass production ( $\mathrm{Ta}$ ble 5 ). Based on surveys of Florida organic growers, hand weeding is the most common method of weed control in organic production systems (Hildebrand et al., 1997; Swisher and Monaghan, 1995). Therefore, the analysis also included the cost of hand weeding during the cash crop following the various fallow treatments using five hand weeding events as the baseline cost for weed management in organic squash production and taking into consideration the weed reduction provided by each treatment (thereby reducing the cost of weeding following certain treatments).

Table 6 provides the breakdown for fertilizer costs used for these analyses. Fertilizer costs were weighted by percentage of organic growers who use poultry manure and fish emulsions as fertilizer sources (Swisher and Monaghan, 1995; Hildebrand et al., 1997). The fertilizer value would vary depending on the growers' practices and cash crop following the summer fallow treatment. In this study, the $\mathrm{N}$ contribution to the following cash crop would reduce the cost of fertilizer needed.

\section{Results and discussion}

Table 7 lists the partial budgets for summer squash production following the five summer fallow treatments. These budgets include the variable costs of each production system and the effects of the $\mathrm{N}$ and weed suppression provided by each treatment on the partial budget. Schomberg et al. (2007) found that sunn hemp accumulated $130 \mathrm{~kg} \cdot \mathrm{ha}^{-1}$ of $\mathrm{N}$ in a 60 -d growing period and assumed that $50 \%$ of the $\mathrm{N}$ would be available for a subsequent

Table 4. Seed and inoculant costs of five summer fallow treatments evaluated for crop rotation with summer squash in Florida.

\begin{tabular}{|c|c|c|c|c|c|c|c|}
\hline Seed $^{\mathrm{z}}$ & Unit & $\begin{array}{l}\text { Quantity } \\
(\text { lb/acre })^{\mathrm{y}}\end{array}$ & $\begin{array}{l}\text { Price } \\
(\$ / 1 b)^{y}\end{array}$ & $\begin{array}{l}\text { Seed cost } \\
(\$ / \text { acre })^{\mathrm{y}}\end{array}$ & $\begin{array}{l}\text { Inoculant cost } \\
(\$ / \text { acre })\end{array}$ & $\begin{array}{c}\text { Total seed and } \\
\text { inoculant cost }(\$ / \text { acre })\end{array}$ & $\begin{array}{l}\text { Total cost } \\
(\$ / \text { acre })\end{array}$ \\
\hline Sunn hemp & Pound & 50.00 & 6.00 & 300.00 & 9.50 & 309.50 & 352.26 \\
\hline Velvet bean & Pound & 30.00 & 8.50 & 255.00 & 9.50 & 264.50 & 307.26 \\
\hline Cowpea & Pound & 100.00 & 1.15 & 115.00 & 9.50 & 124.50 & 167.26 \\
\hline Sorghum-sudangrass & Pound & 40.00 & 2.40 & 96.00 & 0.00 & 96.00 & 138.76 \\
\hline Tillage & & & & & & - & 70.45 \\
\hline
\end{tabular}

${ }^{\mathrm{z}}$ Abdul-Baki and Teasdale, 2007; Adams-Briscoe Seed Co., 2011.

$\mathrm{y} \mathrm{lb} / \mathrm{acre}=1.1209 \mathrm{~kg} \cdot \mathrm{ha}^{-1}, \$ 1.00 / \mathrm{lb}=\$ 2.2046 / \mathrm{kg}, \$ 1.00 / \mathrm{acre}=\$ 2.4711 / \mathrm{ha}$. 
vegetable crop, which for most vegetables would account for half of the required amount. Therefore, this table assumes that at least half of the $\mathrm{N}$ produced by the cover crops would be available for the following cash crop of squash.

These partial budgets illustrate the economic benefits that can be observed from including a summer cover crop (especially a leguminous one) into a production system to reduce fertilizer and weed management costs in a following cash crop (in this case, summer squash). The analysis found that sunn hemp as a cover crop provided the greatest cost reduction, followed by velvet bean, cowpea, sorghum-sudangrass, and all cover crops provided greater cost reduction than conventional tillage. These results may be counterintuitive for growers who often focus only on the direct costs of implementing treatments (Table 4) when making decisions about crop production. The least expensive and simplest management choice is often the preferred, especially since the cost reductions that are included in Table 7 have economic values that cannot easily be estimated.

Table 5. Nitrogen $(\mathrm{N})$ contribution and weed control benefits of five summer fallow treatments evaluated for rotation with summer squash in Florida.

\begin{tabular}{lcccc}
\hline & $\begin{array}{c}\text { Available N } \\
(\mathbf{l b} / \text { acre })^{\mathrm{z}}\end{array}$ & $\begin{array}{c}\text { Dry matter } \\
\text { accumulation } \\
\text { (tons/acre) }\end{array}$ & $\begin{array}{c}\text { Percent weed } \\
\text { reduction } \\
(\%)^{\mathrm{y}}\end{array}$ & $\begin{array}{c}\text { Cost of weeding } \\
\text { in following cash } \\
\text { crop }(\$ / \text { acre })^{\mathrm{x}}\end{array}$ \\
\hline Sunn hemp & 150 & 5 & 70 & 16.35 \\
Velvet bean & 141 & 6 & 84 & 8.72 \\
Cowpea & 43 & 3 & 42 & 31.61 \\
Sorghum-sudangrass & 16.5 & 2 & 28 & 39.24 \\
Fallow & - & - & - & 54.50 \\
\hline
\end{tabular}

${ }^{2} \mathrm{Li}$ et al. 2006; D.D. Treadwell, personal communication; $1 \mathrm{lb} / \mathrm{acre}=1.1209 \mathrm{~kg} \cdot \mathrm{ha}^{-1}, \mathrm{l}$ ton $/ \mathrm{acre}=2.2417$ $\mathrm{Mg} \cdot \mathrm{ha}^{-1}$.

'Sangakkara et al. 2006.

${ }^{x}$ Based on five weeding events of $1 \mathrm{~h}$ each in the cash crop following the summer fallow treatment at $\$ 10.90 / \mathrm{h}$

(Florida Department of Economic Opportunity, 2010); \$1.00/acre $=\$ 2.4711 /$ ha.
Table 7 also adds the production costs of squash following each summer treatment to the cost of the implementation of the summer treatment (Table 4) to create the total comparative costs of each treatment. Although the cost of seed is high for some cover crops such as sunn hemp and velvet bean, the ecological benefits that these cover crops provide is superior to the other treatments and this is reflected in the reduction in production costs for $\mathrm{N}$ and weed management. For example, although sorghum-sudangrass seed is inexpensive, it is not a legume and cannot biologically fix $\mathrm{N}$ like the other cover crops used in this study; therefore, it would not provide as much $\mathrm{N}$ to the following cash crop as a leguminous cover crop would.

\section{Conclusions}

Considering costs for both the summer treatment and the following cash crop (summer squash), velvet bean is the least expensive summer treatment, followed by sunn hemp, cowpea, sorghum-sudangrass, and tillage. Despite the heavy reliance on cost of seed and management for adoption of summer cover crops in place of a clean or weedy fallow, these costs do not incorporate the short- and

Table 6. Fertilizer costs for organic production of summer squash in Florida based on the weighted value of the commonly used sources for fertilizer in organic production systems.

\begin{tabular}{|c|c|c|c|c|c|}
\hline Fertilizer source $^{\mathrm{z}}$ & $\begin{array}{c}\text { Proportion of source } \\
\text { used }(\%)^{\mathrm{y}}\end{array}$ & Unit & $\begin{array}{c}\begin{array}{c}\text { Quantity } \\
\text { (units/acre) }^{x}\end{array} \\
\end{array}$ & $\begin{array}{c}\text { Price } \\
(\$ / \text { unit })^{\mathrm{x}}\end{array}$ & $\begin{array}{c}\text { Cost } \\
(\$ / \text { acre })^{x} \\
\end{array}$ \\
\hline Chicken manure & $38 \%$ & ton & 15 & 23 & 345 \\
\hline Fish emulsion with kelp/seaweed ${ }^{w}$ & $29 \%$ & gallon & 5 & 30.10 & 150.50 \\
\hline Total fertilizer cost & & & & & 415.98 \\
\hline
\end{tabular}

${ }^{\mathrm{z} F e r g u s o n}$ and Ziegler, 2004; Hodges, 2007; McMahon, 2007.

${ }^{y}$ Swisher and Monaghan, 1995.

${ }^{\mathrm{x}} \mathrm{l}$ ton $/$ acre $=2.2417 \mathrm{Mg} \cdot \mathrm{ha}^{-1}, \mathrm{lgal} / \mathrm{acre}=9.3540 \mathrm{~L} \cdot \mathrm{ha}^{-1}, \$ 1.00 /$ ton $=\$ 1.1023 / \mathrm{Mg}, \$ 1.00 / \mathrm{gal}=\$ 0.2642 / \mathrm{L}, \$ 1.00 / \mathrm{acre}=\$ 2.471 \mathrm{l} / \mathrm{ha}$.

wFish Emulsion and Seaweed Blend; Neptune's Harvest, Gloucester, MA.

Table 7. Comparative cost of five summer fallow treatments followed by summer squash for 1 acre ( 0.4 ha) in Florida including the cost of each fallow treatment and benefits from nitrogen production and weed suppression provided by the summer fallow treatments.

\begin{tabular}{|c|c|c|c|c|c|}
\hline Production costs per acre ${ }^{\mathrm{z}}$ & Tillage & Sunn hemp & Velvet bean & Cowpea & Sorghum-sundangrass \\
\hline Fertilizer costs & $\$ 415.98$ & $\$ 0$ & $\$ 24.96$ & $\$ 296.73$ & $\$ 370.22$ \\
\hline Weed management & $\$ 54.50$ & $\$ 16$ & $\$ 8.72$ & $\$ 31.61$ & $\$ 39.24$ \\
\hline Preharvest costs & $\$ 1,618.50$ & $\$ 1,164.37$ & $\$ 1,181.70$ & $\$ 1,476.36$ & $\$ 1,557.48$ \\
\hline Harvest costs & $\$ 811.25$ & $\$ 811.25$ & $\$ 811.25$ & $\$ 811.25$ & $\$ 811.25$ \\
\hline Fixed costs & $\$ 278.80$ & $\$ 278.80$ & $\$ 278.80$ & $\$ 278.80$ & $\$ 278.80$ \\
\hline Total cost of cash crop production & $\$ 2,708.55$ & $\$ 2,254.42$ & $\$ 2,271.75$ & $\$ 2,566.41$ & $\$ 2,647.53$ \\
\hline Cost differential between treatments & $\$ 201.01$ & $\$ 28.67$ & $\$ 0$ & $\$ 145.66$ & $\$ 208.28$ \\
\hline
\end{tabular}

${ }^{\mathrm{z}}$ Refer to Tables 2-6 and Hewitt, 2006; $\$ 1.00 /$ acre $=\$ 2.471 \mathrm{l} / \mathrm{ha}$ 
long-term ecological benefits that cover crops provide to a cropping system. Although this study looked at $\mathrm{N}$ accumulation and weed suppression, there are many other benefits from including a cover crop into a cropping system such as carbon fixation, organic matter production, increasing/ diversifying microbial populations, disrupting disease/insect/weed cycles, water retention, reduction of soil erosion, and other benefits that do not carry economic values with them directly, yet provide benefits to the cropping system (Snapp et al., 2005). One of the major research gaps that exist in the area of ecosystem services in agricultural systems is the lack of measurement and valuation, which needs to be addressed (Swinton et al., 2006). This includes attempting to value the benefits of cover crops to cropping systems mentioned above.

There are many factors that affect the uptake of biologically fixed $\mathrm{N}$, which can include temperature, rainfall, and timing of cover crop mowing and cash crop planting. Weed control by biomass production alone will also have variable results depending on location and production management. Existing weed populations and environmental factors will influence the level of success of weed suppression by the cover crops. Additionally, variability in stand establishment of the cover crop, such as with velvet bean, can lead to poor weed suppression (Bhan, 2010). These factors would vary depending on the grower and their production practices, and therefore these partial budgets may vary depending on the situation. Future research should explore field studies that could verify and quantify the additional cropping system values that summer cover crops could contribute during a summer fallow. Although these data would be dependent upon the location of study, it would be important to verify the economic values presented in this study.

\section{Literature cited}

Abdul-Baki, A.A. and J.R. Teasdale. 2007. Sustainable production of fresh-market tomatoes and other vegetables with cover crop mulches. U.S. Dept. Agr. Farmer's Bul. 2280 .

Adams-Briscoe Seed Co. 2011. Seed List. 27 Feb. 2011. <http://abseed.com/ graphics/seedlist/prices.pdf/>.

Bhan, M. 2010. Cropping system complexity for suppressing pests in organic vegetable production. Univ. of Florida, Gainesville, PhD Diss.

Downs, H.W. and R.W. Hansen. 1998. Estimating Farm Fuel Requirements. Colorado State Univ. Ext. Serv. Farm Ranch Ser. No. 5.006. 28 Mar. 2009. <http:// www.cde.state.co.us/artemis/ucsu20/ ucsu2062250061998internet.pdf>.

Ferguson, J.J. and M.R. Ziegler. 2004. Guidelines for Purchase and Application of Poultry Manure for Organic Crop Production. 28 Mar. 2009. <http://edis.ifas. ufl.edu/HS217>.

Florida Department of Economic Opportunity. 2010. Occupational Employment Statistics and Wages. 13 Jan. 2012. <http://www.floridajobs.org/ labor-market-information/data-center/ statistical-programs/occupationalemployment-statistics-and-wages $>$

Froud-Williams, R.J., R.J. Chancellor, and D.S.H. Drennan. 1983. Influence of cultivation regime upon buried weed seeds in arable cropping systems. J. Appl. Ecol. 20:199-208.

Hewitt, T.D. 2006. Estimated Costs of Producing One Acre of Squash on Plastic for Fresh Market, North Florida. 15 Feb. 2009. <http://nfrec.ifas.ufl.edu/ program/enterprise_budgets.shtml>.

Hildebrand, P., D. Zimet, G. Brinen (eds.). 1997. Organic Agricultural Production in North and Central Florida: A Sondeo Report. 29 Mar. 2009. <http://ufdc.ufl. edu/UF00053845/00001/2j>.

Hodges, A.W. 2007. Economic analysis of integrated weed control in organic vegetable production final project report to USDA-SARE. Univ. of Florida, Gainesville.

Klassen, W., M. Codallo, I.A. Zasada, and A.A. Abdul-Baki. 2006. Characterization of velvet bean (Mucuna pruriens) lines for cover crop use. Proc. Florida State Hort. Soc. 119:258-262.

Li, Y., A. Hanlon, W. Klassen, Q. Wang, T. Olczyk, and I.V. Ezenwa. 2006. Cover Crop Benefits for South Florida Commer- cial Vegetable Producers. 30 June 2009. <http://edis.ifas.ufl.edu/SL242.pdf>.

Lu, Y.C., K.B. Watkins, J.R. Teasdale, and A.A. Abdul-Baki. 2000. Cover crops in sustainable food production. Food Rev. Int. 16:121-157.

McMahon, K. 2007. Waste Not. 28 Nov. 2009. <http://farmindustrynews.com/ mag/waste_not_manure/index.html>.

Sangakkara, U.R., P.R.S.D. Bandaranayake, D.N.K. Weerakekera, and P. Stamp. 2006. Interseasonal cropping- its potential for managing weeds in the Asia tropics. J. Plant Dis. Protection 20:921-927.

Schomberg, H.H., N.L. Martini, J.C. Diaz-Perez, S.C. Phatak, K.S. Balkcom, and H.L. Bhardwaj. 2007. Potential for using sunn hemp as a source of biomass and nitrogen for the piedmont and coastal plain regions of the southeastern USA. Agron. J. 99:1448-1457.

Snapp, S.S., S.M. Swinton, R. Labarta, D. Mutch, J.R. Black, R. Leep, J. Nyiraneza, and K. O'Neil. 2005. Evaluating cover crops for benefits, costs and performance within cropping system niches. Agron. J. 97:322-332.

Swinton, S.M., F. Lupi, G.P. Robertson, and D.A. Landis. 2006. Ecosystem services from agriculture: Looking beyond the usual suspects. Amer. J. Agr. Econ. 88:1160-1166.

Swisher, M.E. and P. Monaghan. 1995. Florida's Organic Farmers: A Profile. J. Ext. 33:3. 20 Feb. 2012. <http:// www.joe.org/joe/1995june/rbl.php>.

U.S. Department of Agriculture. 2000. National Organic Program. U.S. Dept. Agr., Washington DC.

U.S. Department of Agriculture. 2009. Census of agriculture. U.S. Dept. Agr., Washington DC.

U.S. Department of Agriculture. 2010. Census of agriculture: Organic production survey. U.S. Dept. Agr., Washington DC.

U.S. Energy Information Administration. 2012. Short-Term Energy Outlook: Real Prices Viewer. 13 Jan. 2012. <http:// www.eia.gov/forecasts/steo/realprices/>.

Walz, E. 1999. Third biennial national organic farmers' survey. Organic Farming Research Foundation, Santa Cruz, CA. 